\begin{tabular}{c|c|}
\hline \hline \hline & International Journal of Current Research \\
P & and Academic Review \\
ISSN: 2347-3215 (Online) Volume 9 Number 01 (January-2021) \\
Journal homepage: http://www.ijcrar.com
\end{tabular}

doi: https://doi.org/10.20546/ijcrar.2021.901.002

\title{
Phytochemical Study and Antioxidant Activity of Annona muricata (Annonaceae) and Corchorus olitorius (Tiliaceae) Two Medicinal Plants from the Ivorian Pharmacopoeia Used in the Treatment of Diabetes
}

\author{
Abba P. Obouayeba ${ }^{1,3^{*}}$, Obou C. Okou ${ }^{1,3}$, Bognan J.A.A. Ackah ${ }^{1,3}$, Bi-Tra L. Tra ${ }^{1}$, Tanoh H. \\ Kouakou $^{2}$, Allico J. Djaman ${ }^{3}$ and Jean D. N'guessan ${ }^{3}$ \\ ${ }^{1}$ Laboratory of Agrovalorisation, Department of Biochemistry-Microbiology, UFR Agroforestry, Jean Lorougnon \\ Guédé University, Daloa, Côte d'Ivoire \\ ${ }^{2}$ Laboratory of Biology and Crop improvement, UFR of Sciences of Nature, Nangui Abrogoua University, Abidjan, \\ Côte d'Ivoire \\ ${ }^{3}$ Laboratory of Biology and Health, UFR Biosciences, Université Félix Houphouet-Boigny, 22 BP 582 Abidjan 22
}

*Corresponding author

\section{Abstract}

Annona muricata and Corchorus olitorius are two medicinal plants whose leaves are widely used in Ivory Coast both in nutrition and for the treatment of various pathologies because of their phytochemical compositions. The objective of this study was to determine the phytochemicals and to assess the antioxidant property of the leaves of these two plants. The phytochemical study was carried out using tests for the identification and quantification of phytoconstituents. As for the study of antioxidant activity, it was carried out by measuring the anti-free radical activity either by ABTS or by DPPH. Qualitative phytochemical screening revealed the presence of flavonoids, polyphenols, saponins, sterols, catechetical tannins and terpenes. The quantitative phytochemical screening of the extracts showed that the content of flavonoids $(329.10 \pm 2.51 \mathrm{mg}$ Eq quercetin $/ \mathrm{Kg}$ ) and that of polyphenols $(82.09 \pm 0.13 \mathrm{mg} \mathrm{Eq} \mathrm{gallic} \mathrm{acid/g)} \mathrm{of} \mathrm{Annona} \mathrm{muricata}$ are higher than the content of flavonoids $(178.45 \pm 1.09 \mathrm{mg}$ Eq quercetin/ $\mathrm{Kg})$ and that of polyphenols $(67.98 \pm 5.22 \mathrm{mg}$ Eq gallic acid/g) of Corchorus olitorius. The results of the antioxidant activity by measurement of the ABTS radical shows that the aqueous extract of Annona muricata exhibits the best activity with an $\mathrm{IC}_{50}$ value of $1.79 \pm 0.15 \mu \mathrm{M}$, while the aqueous extract of Corchorus olitorius records an $\mathrm{IC}_{50}$ value of $2.64 \pm 0.05 \mu \mathrm{M}$. Similar results are observed with the measurement of DPPH. The various metabolites demonstrated have various therapeutic properties which may be involved in the treatment of diabetes. This would confirm the therapeutic use reported by the populations. However, the evaluation of the antimalarial, antibacterial and anti-inflammatory activities as well as the toxicity test of the aqueous extract of these plants would be necessary.
\end{abstract}

\section{Introduction}

For thousands of years, humanity has used various plants found in its environment to treat and cure all kinds of
Article Info

Accepted: 08 December 2020

Available Online: 20 January 2021

\section{Keywords}

Annona muricata, Corchorus olitorius, Aqueous extracts, Phytochemicals, Antioxidant property. 
biological activities (Okou et al., 2020). Medicinal plants are still the first reservoir of new drugs, they are considered as a source of essential raw material for the discovery of new molecules necessary for the development of future drugs. This plant material contains a large number of molecules that have multiple interests used in the food industry, cosmetology and pharmacy. Among these compounds, we find coumarins, alkaloids, phenolic acids, tannins, terpenes and flavonoids (Yayé et al., 2020).

Oxidative stress is involved in many diseases as a trigger or associated with complications, most diseases induced by oxidative stress appear with age because aging decreases antioxidant defenses increase the mitochondrial multiplication of radicals, among the activities biologicals of medicinal plants, in recent years attention has focused on antioxidant activity due to the role it plays in the prevention of chronic diseases such as heart disease, cancer, diabetes, hypertension, and Alzheimer's disease by combating oxidative stress (Meddour et al., 2013).

Diabetes mellitus is a group of metabolic diseases characterized by chronic hyperglycemia resulting from defective insulin secretion and/or the action of this hormone (Raccah, 2004). The treatments for this condition consist in controlling the blood sugar level of patients by dietary measures, oral antidiabetics or by insulin therapy for type 2 diabetics, and only by insulin therapy in the case of type 1 diabetics (Charbonnel et al., 1997).

Diabetes and its complications have significant socioeconomic repercussions. This disease can damage blood vessels, nerves, eyes and kidneys. Diabetes can lead to high blood pressure and interfere with heart activity.

The high costs of conventional treatments direct diabetics to traditional remedies (Obouayeba et al., 2020). According to the World Health Organization (WHO), around $65-80 \%$ of the world's population in underdeveloped countries, due to poverty and lack of access to modern medicine, depend mainly on medicinal plants traditional for their primary health care (Obouayeba et al., 2019).

\section{Objective of research}

The development of medicinal plants from the traditional Ivorian pharmacopoeia, with the aim of researching new bioactive substances for the development of herbal medicines is at the origin of this study. The present work aims to study the phytochemistry and the antioxidant property of Annona muricata and Corchorus olitorius.

To achieve this general objective, three specific objectives have been defined, namely: determine certain physicochemical parameters; look for the main chemical groups present in the aqueous extracts of the leaves of the two plants; evaluate the antioxidant activity of aqueous extracts from the leaves of these plants.

\section{Materials and Methods}

\section{Plant material}

Dried leaves of Annona muricata and Corchorus olitorius were used as plant material in this study. Samples of the plant material used were collected in the Haut-Sassandra region (Daloa, Côte d'Ivoire). The leaves of these plants were subjected to different treatments separately. They were cut up, cleaned, washed thoroughly with water, drained and dried in an oven at 55 ${ }^{\circ} \mathrm{C}$ for 12 hours. After drying, the plant elements were finely ground in an electric grinder to obtain a powder. These samples were then packaged in polyethylene bags and stored at $4{ }^{\circ} \mathrm{C}$ for laboratory analysis.

\section{Reagents and chemicals}

The chemicals used for the extraction, dosage and identification of phytocompounds are: methanol $(\mathrm{MeOH})$, ferric chloride, ethanol (EtOH), hydrochloric acid $(\mathrm{HCl})$, isoamyl alcohol, potassium iodobismuth from Sigma-Aldrich (Steinheim, Germany), Stisany's reagent, Dragendorff's reagent, acetic anhydride, sulfuric acid, Folin-Ciocalteu reagent, calcium carbonate, gallic acid, sodium nitrite (NaNO2), aluminum chloride $\left(\mathrm{AlCl}_{3}\right)$, sodium hydroxide $(1 \mathrm{~N} \mathrm{NaOH})$, quercetin were obtained from Merck (Darmstadt, Germany).

The reagents and chemicals used in the antioxidant study are as follows: 2,2'-azinobis-3-ethylbenzothiazoline-6sulfonic acid, Trolox, 2,2'-diphenyl-1-picrylhydrazyl (DPPH), Quercetin, methanol (MeOH), ethanol (EtOH).

\section{Technical material}

The technical equipment which was used to carry out this work consisted of: analytical balance, BÜCHI R-114 rotary evaporator, spectrophotometer, oven, IKAMAG RCT type stirrer, common laboratory glassware. 


\section{Extract preparations}

This operation was carried out according to the method described by Zirihi et al., (2010) with some modifications in plant material and solvent.

One hundred grams (100 g) of vegetable powder from each plant (Annona muricata and Corchorus olitorius) obtained previously by grinding were macerated with magnetic stirring on an IKAMAG RCT type stirrer in 1 $\mathrm{L}$ of distilled water for 24 hours. The resulting homogenate was first drained in a square piece of cloth, then filtered successively twice through cotton wool and once through Whatman $3 \mathrm{~mm}$ paper. The water was then evaporated in vacuo at reduced pressure with a rotary evaporator (BÜCHI R-114) at $38{ }^{\circ} \mathrm{C}$. The solution obtained is distributed into glass boxes and placed in an oven at $50{ }^{\circ} \mathrm{C}$. The powders obtained after drying in an oven constituted the total aqueous extracts used for the various analyzes.

The method of preparation of these extracts is summarized in figure 1 as follows:

\section{Physicochemical parameters}

\section{Humidity level}

The moisture content of the plant was determined by the drying process. A quantity of fresh leaves with a mass of $5 \mathrm{~g} \pm 0.01$ was exposed to a temperature of $103{ }^{\circ} \mathrm{C} \pm 5$ in an oven until a constant weight was obtained. The humidity level is calculated by the following formula:

$\mathrm{H}(\%)=\left[\left(\mathrm{M}_{0}-\mathrm{M}_{1}\right) / \mathrm{M}_{0}\right] \times 100$

$\mathrm{M}_{0}$ : Mass of the sample "before drying in grams". $\mathrm{M}_{1}$ : Mass of the sample "after drying in grams". $\mathrm{H}(\%)$ : Humidity rate expressed as a percentage.

The dry matter content is calculated according to the following relationship:

Dry matter MS $\%=100-\mathrm{H} \%$

\section{Yield}

The yield is calculated by carrying out a ratio between the mass of the extract collected after drying in the oven and the mass of the dried material, the ratio thus obtained is multiplied by 100 . The extraction yield is expressed as a percentage and calculated by the formula given by (Falleh et al., 2007):

$\mathrm{R}(\%)=\left(\mathrm{M}_{\mathrm{ext}} / \mathrm{M}_{\mathrm{sam}}\right) \times 100$

Or:

$\mathrm{R}$ : the yield in (\%).

$\mathrm{M}_{\text {ext }}$ : the mass of the extract after evaporation of the solvent in $(\mathrm{g})$.

$\mathrm{M}_{\text {sam}}$ : the dry mass of the plant sample in $(\mathrm{g})$.

\section{Qualitative phytochemical screening}

Phytochemical screening makes it possible to demonstrate, from coloring and precipitation reactions, the presence or absence of different families of secondary metabolites such as alkaloids, polyphenols, tannins, flavonoids, saponins, polyterpenes and sterols. The presence of some phytoconstituents in the extract was highlighted by standards phytochemical methods.

\section{Search for polyphenols}

To $2 \mathrm{~mL}$ of plant extract was added a drop of $2 \%$ aqueous ferric chloride solution. The appearance of a blackish blue or green color, more or less dark, indicates the presence of phenolic compounds.

\section{Search for flavonoids}

A volume of $2 \mathrm{~mL}$ of the plant extract was evaporated to dryness. After cooling, the residue was taken up in $5 \mathrm{~mL}$ of hydrochloric alcohol (obtained by mixing $10 \mathrm{~mL}$ of 96 - ethanol, $10 \mathrm{~mL}$ of distilled water and $10 \mathrm{~mL}$ of concentrated hydrochloric acid) diluted 2 times in a tube with test. Then 2 or 3 magnesium shavings were added for the release of heat. Adding 3 drops of isoamyl alcohol to the mixture causes a pinkish-orange or purplish color to form, indicating the presence of flavonoids.

\section{Search for alkaloids}

A test portion of $6 \mathrm{~mL}$ of plant extract was evaporated. The residue was taken up in $6 \mathrm{~mL}$ of $60^{\circ}$ alcohol. The alcoholic solution thus obtained is placed in a test tube and 2 drops of Dragendorff's reagent (aqueous solution of potassium iodo-bismuth) have been added. The appearance of a precipitate or an orange color indicates the presence of alkaloids. 


\section{Search for tannins}

\section{Search for catechetical tannins}

A volume of $5 \mathrm{~mL}$ of plant extract was evaporated and then to dryness, $15 \mathrm{~mL}$ of Stisany's reagent $(10 \mathrm{~mL}$ of $40 \%$ formalin supplemented with $5 \mathrm{~mL}$ of concentrated $\mathrm{HCl}$ ) was added. The mixture was kept in a water bath at $80{ }^{\circ} \mathrm{C}$ for 30 minutes then, cooled under running water. The observation of large precipitates in flakes characterizes the catechetical tannins.

\section{Search for gallic tannins}

The solution containing the flakes is filtered and the collected filtrate was saturated with sodium acetate. Then to the mixture, 3 drops of $2 \%$ ferric chloride were added. The appearance of an intense blue-black color indicates the presence of Gallic tannins.

\section{Search for saponin}

A volume of $10 \mathrm{~mL}$ of the extract was put into a test tube, then the whole was stirred for a few minutes and the foam height was measured. A foam height greater than $1 \mathrm{~cm}$ indicates the presence of saponins. Saponins can also be highlighted by the persistence of the foam.

\section{Search for polyterpenes and sterols}

A volume of $5 \mathrm{~mL}$ of plant extract was dried under a rotary evaporator. The residue was dissolved in $1 \mathrm{~mL}$ of acetic anhydride while hot and collected in a test tube. Then $0.5 \mathrm{~mL}$ of concentrated sulfuric acid was poured down the tube. The appearance of a purple or violet ring at the interphase, turning blue and then green, indicates the presence of polyterpenes and sterols.

\section{Quantitative phytochemical screening}

\section{Determination of total polyphenol content}

The method of Wood et al., (2002) was used for the determination of total polyphenols. A volume of $2.5 \mathrm{~mL}$ of diluted Folin-Ciocalteu reagent (1/10) was added to 30 $\mu \mathrm{L}$ of plant extract. The mixture was kept for 2 minutes in the dark at room temperature, then $2 \mathrm{~mL}$ of calcium carbonate solution $\left(75 \mathrm{~g} . \mathrm{L}^{-1}\right)$ was added. Then the mixture was placed for 15 minutes in a water bath at 50 ${ }^{\circ} \mathrm{C}$, then cooled rapidly. Absorbance was measured at $760 \mathrm{~nm}$, with distilled water as a blank. A calibration line was performed with gallic acid at different concentrations. The analyzes were performed in triplicate and the concentration of polyphenols was expressed in milligram gallic acid equivalent per gram of extract (mg Eq A.G/g).

\section{Determination of the total flavonoid content}

The determination of the total flavonoids was carried out according to the method described by Marinova et al., (2005). In a $25 \mathrm{~mL}$ vial, $0.75 \mathrm{~mL}$ of $5 \%(\mathrm{w} / \mathrm{v})$ sodium nitrite $\left(\mathrm{NaNO}_{2}\right)$ was added to $2.5 \mathrm{~mL}$ of the extract. To the mixture was added $0.75 \mathrm{~mL}$ of $10 \%$ (w/v) aluminum chloride $\left(\mathrm{AlCl}_{3}\right)$, then incubated for 6 minutes in the dark. After incubation, $5 \mathrm{~mL}$ of sodium hydroxide (1N $\mathrm{NaOH}$ ) was added and then the volume was made up to $25 \mathrm{~mL}$. The mixture was stirred vigorously before being assayed with a UV-visible spectrophotometer. The reading was taken at $510 \mathrm{~nm}$. The tests were carried out in triplicate. The flavonoid content was expressed in milligram quercetin equivalent per kilogram of extract (mg Eq Q/Kg).

\section{Evaluation of antioxidant activity}

\section{Measurement of anti-free radical activity by ABTS}

This method is based on the ability of the compounds to reduce the $\mathrm{ABTS}^{+^{\circ}}$ radical-cation (2,2'-azinobis-3ethylbenzothiazoline-6-sulfonic acid). The test was carried out according to the method described by Choong et al., (2007). The $\mathrm{ABTS}^{\circ}$ radical-cation was produced by reacting $8 \mathrm{mM}$ ABTS $(87.7 \mathrm{mg}$ in $20 \mathrm{~mL}$ of distilled water) and $3 \mathrm{mM}$ of potassium persulfate $(0.0162 \mathrm{~g}$ in 20 $\mathrm{mL}$ of distilled water) in a ratio $1: 1(\mathrm{v} / \mathrm{v})$. The mixture was then incubated in the dark at room temperature for 12-16 hours. This solution of $\mathrm{ABTS}^{\circ+}$ was diluted with methanol to obtain a solution with an absorbance of $0.7 \pm$ 0.02 at $734 \mathrm{~nm}$. Thus, a test portion of $3.9 \mathrm{~mL}$ of this diluted $\mathrm{ABTS}^{\circ+}$ solution was added to $100 \mu \mathrm{L}$ of the test compound. After stirring, the mixture was incubated for 6 minutes in the dark $\left(\mathrm{T}=30 \pm 2{ }^{\circ} \mathrm{C}\right)$. The residual absorbance of the $\mathrm{ABTS}^{+{ }^{\circ}}$ radical was then measured at $734 \mathrm{~nm}$ with a UV-visible spectrophotometer and should be between $20 \%-80 \%$ of the absorbance of the blank. The tests were carried out in triplicate and the results were expressed in $\mu \mathrm{mol}$ Trolox equivalent per liter of extract $(\mu \mathrm{mol} \mathrm{TE} / \mathrm{L})$. A calibration line was performed with the following concentrations of Trolox: $0.375 \mu \mathrm{M}$; $0.5 \mu \mathrm{M} ; 0.625 \mu \mathrm{M} ; 1 \mu \mathrm{M} ; 1.125 \mu \mathrm{M}, 1.375 \mu \mathrm{M}$ and 1.5 $\mu \mathrm{M}$ and the rate of inhibition $(\% \mathrm{I})$ of $\mathrm{ABTS}^{\circ+}$ was expressed as follows: 
$\% \mathrm{I}=\left[\left(\mathrm{A}_{0}-\mathrm{Abs}_{\mathrm{sam}}\right) / \mathrm{A}_{0}\right] \times 100$

$\mathrm{A}_{0}=$ diluted ABTS absorbance,

$\mathrm{Abs}_{\mathrm{sam}}=$ diluted ABTS absorbance + sample.

This line made it possible to express the antioxidant activity of the different extracts as follows:

Antioxidant concentration or activity $(\mu \mathrm{M}$ eq Trolox $)=$ (\% I x fd $) /(4.99 \times 10)$

Concentration of extract before dilution $=0.1 \mathrm{~g} / 25 \mathrm{~mL}$

\section{Measurement of anti-free radical activity by DPPH}

The measurement of the anti-free radical activity of the plant extracts was carried out by the 2,2'-diphenyl-1picrylhydrazyl (DPPH) test according to the method of Parejo et al., (2000) with some modifications. A range of concentrations $(0-200 \mu \mathrm{g} / \mathrm{mL})$ of plant extract or Quercetin (reference antioxidant) is prepared in ethanol / water $(70 / 30)(\mathrm{v} / \mathrm{v})$. A volume of $100 \mu \mathrm{L}$ of this solution is mixed with $3.9 \mathrm{~mL}$ of $\mathrm{DPPH}(70 \mu \mathrm{M})$ prepared in methanol. After homogenization, the mixture is incubated at room temperature $\left(25^{\circ} \mathrm{C}\right)$ protected from light. After 15 minutes of incubation, the absorbance is read at $517 \mathrm{~nm}$ against a "blank" which contains only methanol. The percentage inhibition of the DPPH radical is calculated according to the following equation:

DPPH inhibition $(\%)=\left(\mathrm{A}_{0}-\mathrm{A}_{\text {extract }} / \mathrm{A}_{0}\right) \times 100$.

The $\mathrm{Cl}_{50}$, which is the concentration of extract or of Quercetin responsible for 50\% inhibition of DPPH radicals, is determined by projection from $50 \%$ on the graph representing the percentage of inhibition of DPPH as a function of the concentrations of the extracts. and Quercetin. (\% DPPH inhibition $=\mathrm{f}$ (extract concentration).

\section{Statistical analysis}

Data were entered and analyzed with SPSS statistical software version 7.5. Three databases were created from studies of quantitative phytochemical screening, evaluation of antioxidant activity by ABTS and DPPH. Means were determined from replicates $(n=3)$. The values presented are expressed as means with one standard deviation. The comparison of means was carried out by analysis of variance (one-way ANOVA), according to the Newman-Keuls test. The various statistical tests are considered significant when $\mathrm{p}<0.05$.

\section{Results and Discussions}

\section{Physicochemical parameters}

The physicochemical parameters that were the subject of this study are: humidity and yield. These parameters are involved in the process of preparing plant extracts. The results of the humidity study show that Annona muricata leaves contain more water with a humidity level of $25 \%$ corresponding to $75 \%$ dry matter (DM). Those of Corchorus olitorius which have a moisture content of $12 \%$ or $88 \%$ dry matter (DM). These results are shown in table 1 . The difference in the contents of our water samples compared to each other, may be due to certain ecological factors, the age of the plant, the period of the vegetative cycle, or even to genetic factors (Albu et al., 2004). Regarding the yield which highlights the level of extraction, its efficiency depends on several parameters such as the diameter of the particles of the powder, the volume and type of solvent used and the number of extractions. The results of this study show that the aqueous extract of Annona muricata gives a higher yield $(14.5 \pm 0.04 \%)$ compared to the aqueous extract of Corchorus olitorius $(13.34 \pm 0.05 \%)$. These data are presented in table 2. By comparing our results with those of certain studies, we observe that our values are different from those of Thaouab et al., (2019) who recorded yields of $17.12 \%$ and $9.56 \%$ respectively for the aqueous extract of Corchorus olitorius and that of Annona muricata. In addition, Naik and Sellappan (2019) recorded a yield of $17 \%$ from the extract of Annona muricata obtained with the fresh leaves of this plant. These authors also obtained a yield of $12 \%$ with the extract of Annona muricata from the dried leaves. These differences in values noted on both sides are explained by the fact that the extraction yield varies according to the plant species used in the extraction, the drying conditions, the content of each species in metabolite and the nature of the solvent used in the extraction or fractionation and its polarity Thaouab et al., (2019). According to Quy-Diem et al., (2014) the extraction yield also depends on several parameters such as: solvent, $\mathrm{pH}$, temperature, extraction time and sample composition. Finally, the combined use of water and the organic solvent can facilitate the extraction of chemicals that are soluble in water and / or in the organic solvent (Quy-Diem et al., 2014). 


\section{Phytochemical study}

\section{Qualitative phytochemical screening}

The qualitative phytochemical study of the aqueous extracts of the leaves of Annona muricata and of Corchorus olitorius made it possible to obtain the results presented in table 3 . The results of this analysis show that the extracts of the leaves of these two plants contain practically the same. phytoconstituents except sterols and terpenes which are peculiar to Annona muricata. The phytochemicals present in the two plant extracts are: flavonoids, polyphenols, saponins and catechetical tannins. However, phytochemical analysis reveals the absence of alkaloids and gallic tannins common to extracts from these plants. The study of medicinal values of plants using qualitative phytochemical analyzes has been the subject of several works (Ongoka et al., 2006; Mungole and Chaturvedi, 2011). Phytochemistry is very important in the identification of new sources of molecules having either a therapeutic role, an industrial role or even both at the same time. A large number of medicinal plants have therefore been chemically studied using this science (Maganha et al., 2010; Li and Du, 2012). The phytochemical tests consist in determining the various compounds existing in the extracts of the plant by qualitative reactions. These latter are based on phenomena of precipitation or colorations by reagents specific to each family of compounds.

The qualitative phytochemical screening of Annona muricata and Corchorus olitorius is in agreement with the work of Falodun et al., (2011), Borokini and Omotayo (2012), Vya et al., (2013), Vijayameena et al., (2013) and Olanrewaju et al., (2016). Other phytochemical studies carried out from the ethanolic extract of the dried leaves revealed Annona muricata revealed the presence of flavonoids, alkaloids, glycosides, tannins, triterpenoids, saponins and reducing sugars (Usunobun et al., 2015; Usunomena and Paulinus, 2015; Mohamed et al., 2017). In addition, the presence of alkaloids in leaves, seeds, roots and stem bark has been reported by Zine et al., (2018). However, our results differ from those of some authors such as Qorina et al., (2019) who demonstrated the presence of alkaloids and gall tannins from the extract of Annona muricata leaves using other solvents (ethanol, methanol, n-hexane and ethyl acetate). In addition, the presence of alkaloids is also noted in the methanolic extract of the leaves of Corchorus olitorius (Sadat et al., 2017). These secondary metabolites have many biological and therapeutic properties. Likewise, Shimizu et al., (2000) reported that phenolic compounds such as flavonoids exert their antidiabetic effect through the liver by influencing gluconeogenesis, glycogen genesis and glycogenolysis. They promote the storage of glucose in the liver and reduce the breakdown of glycogen. According to Sarkhail et al., (2007), flavonoids influence the beta cells of islets of Langerhans in the pancreas and stimulate the secretion of insulin. These facts are supported by Palsamy and Subramanian (2008) who showed the same effect in diabetic rats treated with resveratrol, a flavonoid. The flavonoids are thought to contribute to the reduction of intestinal glucose absorption in diabetic rats induced by streptozotocin (Zurina et al., 2010).

\section{Quantitative phytochemical screening}

The results of the quantitative phytochemical study of the aqueous extracts of the leaves of Annona muricata and Corchorus olitorius are contained in table 4. These results, which relate to the content of flavonoids and polyphenols in the extracts of the leaves of these two plants show that Annona muricata is richer in flavonoids and polyphenols than Corchorus olitorius. Indeed, the contents of these phytochemicals are more important in Annona muricata with respectively concentrations of $329.1 \mathrm{mg} \mathrm{Eq}$ of quercetin/Kg concerning the flavonoids and of $82.09 \mathrm{mg} \mathrm{Eq}$ of gallic acid/g at the level of the polyphenols. As for Corchorus olitorius, displays concentrations of $178.45 \mathrm{mg} \mathrm{Eq}$ of quercetin/ $\mathrm{Kg}$ for flavonoids and $67.98 \mathrm{mg} \mathrm{Eq}$ of gallic acid/g for polyphenols.These results differ from the results of Thaouab et al., (2019) who found a value of $60.74 \pm 0.42$ $\mathrm{mg} \mathrm{Eq}$ of quercetin $/ \mathrm{Kg}$ with the aqueous extract of $C$. olitorius and a value of $71.35 \pm 0.70 \mathrm{mg} \mathrm{Eq}$ quercetin $/ \mathrm{Kg}$ with the aqueous extract of $C$. olitorius concerning flavonoids. This similarity also appears in total polyphenols, with the aqueous extract of $C$. olitorius which gives a total polyphenol value of $7.01 \pm 0.87 \mathrm{mg}$ EAG/g and the methanolic extract of this plant has a value of $5.04 \pm 1.60 \mathrm{mg}$ of EAG/g. The results recorded for Annona muricata are $329.10 \pm 2.51 \mathrm{mg} \mathrm{Eq}$ quercetin/Kg for total flavonoids and $82.09 \pm 0.13 \mathrm{mg}$ EAG/g for total polyphenols. This situation reflects the richness of Annona muricata in these phytochemicals compared to Corchorus olitorius. The quantitative values of our results concerning Annona muricatafor the same phytocompounds are higher than those obtained by Olanrewaju et al., (2016). This author recorded a value of $70.67 \pm 0.8753 \mathrm{mg} \mathrm{Eq}$ quercetin/Kg for flavonoids and a value of $16.6 \pm 0.53 \mathrm{mg} \mathrm{EAG} / \mathrm{g}$ for total polyphenols. 
Flavonoids are endowed with hypoglycemic and antidiabetic properties according to the results of several studies carried out (Kim et al., 2006; Kebieche, 2009). Several mechanisms are attributed to flavonoids for this activity. According to these authors (Huang et al., 2004; Raccah, 2004) flavonoids prevent diabetes by inhibiting alkalosis reductase. In addition, several studies have shown that the consumption of foods rich in flavonoids is inversely correlated with the risk of developing cardiovascular diseases (Pietta, 2000; Hollman, 2001) and also confirmed by Ouldyerou et al., (2018). Extraction methods may affect results due to the solubility of phenolic compounds. In addition, the plant material was harvested from regions different from ours and the distribution of secondary metabolites may change during plant development (Zidorn, 2010), the extraction of phenolic compounds is also influenced by time and extraction temperature, reflecting the paradoxical actions of solubilization and oxidative degradation. Therefore, it is important to make the correct choice of extraction procedure/method in order to maintain the stability of the phenolic compounds (Turkmen et al., 2007).

\section{Antioxidant activity}

On examining these results, it can be seen that the leaf extracts expressed a good anti-free radical effect against the ABTS radical. The aqueous extract of Annona muricata shows the best activity with an $\mathrm{IC}_{50}$ value of $1.79 \pm 0.15 \mu \mathrm{M}$, while the aqueous extract of Corchorus olitorius has an $\mathrm{IC}_{50}$ value of $2.64 \pm 0.05 \mu \mathrm{M}$. However, these results are lower than the results obtained with Trolox $\left(\mathrm{IC}_{50}\right.$ of $\left.0.95 \pm 0.12 \mu \mathrm{M}\right)$ used as reference molecule (Table 5).

From these results, it can be seen that the percentage inhibition of the free radical increases with increasing concentration. The DPPH inhibition rates recorded in the presence of the various extracts are lower than those of quercetin. The total aqueous extracts of the leaves of Annona muricata and Corchorus olitorius exhibited a powerful anti-free radical effect against the DPPH radical starting from the concentrations 750 and 1000 $(\mathrm{mg} / \mathrm{mL})$ where we have an anti-free radical activity of the extracts of the two plants equivalent to two thirds and half that of quercetin (Table 6). The phenolic compounds seem to be good candidates for their antioxidant activities due to the presence of many hydroxyls which can react with free radicals (Govindan and Muthukrishnan, 2013). The presence of a catechol group is the major determinant of the redox activity of polyphenols (Roudsari et al., 2009). Studies have shown that the chemical structure and polarity of the antioxidant are critical to its ability to scavenge free radicals. There is structural heterogeneity within phenolic compounds, which heterogeneity results in different properties. They showed that gallic acid is the most active compound, using DPPH the antioxidant power of epicatechin is not significantly different, and tannic acid gave the values about 5 times lower (Popovici et al., 2009). According to the literature there is a relationship between the structure of polyphenols and their ability to scavenge free radicals. It has been suggested that the polar molecules present in plant extracts contribute to the increase in anti-free radical activity (Wang et al., 2008). Polyphenols and more particularly flavonoids are thermodynamically capable of rapidly reducing superoxide, peroxide (ROO $\bullet$ ), alkoxyl (RO •) and hydroxyl radicals by hydrogen transfer (Morand and Milenkovic, 2014). Given the importance of antioxidant agents clinically and their role in the prevention of several diseases due to oxidative stress, several studies are being carried out in order to find new molecules endowed with this property, medicinal plants constitute a source. inexhaustible given the diversity of their secondary metabolites. At the same time, at the experimental level, several methods have been developed for the evaluation of antioxidant activity. Among them, some are testing the inhibitory power of these molecules for the free radical-producing enzymes that cause oxidative stress, while others are trying to assess the anti-free radicals' power. In vitro, these methods are based exclusively on the free radical scavenging capacity of a compound as an indicator of its antioxidant potential (Marc et al., 2004).

The anti-free radical activities of the aqueous extracts of the leaves of Annona muricata and ofCorchorus olitorius showed that the aqueous extract of the leaves of Annona muricata is more active than that of the leaves of Corchorus olitorius on all three tests carried out with lower $\mathrm{IC}_{50}$. Furthermore, at the same concentrations tested, the inhibition percentages obtained by the DPPH test are higher than those of the ABTS method. This could be explained by the presence of substances which exhibit absorption bands at the same wavelength as the $\mathrm{DPPH}^{\cdot}$ radical, thus leading to an increase in absorbance (Sarr et al., 2015). 
Table.1 Moisture rate of leaves of Corchorus olitorius and Annona muricata

\begin{tabular}{lccc}
\cline { 2 - 4 } & $\mathbf{M}_{\mathbf{0}}(\mathbf{g})$ & $\mathbf{M}_{\mathbf{1}}(\mathbf{g})$ & H (\%) \\
\hline Annona muricata & 8 & 6 & 25 \\
Corchorus olitorius & 5 & 4,5 & 12 \\
\hline
\end{tabular}

$\mathrm{M}_{0}$ : Mass of the sample "before drying in grams"; $\mathrm{M}_{1}$ : Mass of the sample "after drying in grams"; $\mathrm{H}(\%)$ : Humidity rate expressed as a percentage.

Table.2 Yield of aqueous extract of Annona muricata and Corchorus olitorius

$\begin{array}{lll}\text { Extract Annona muricata Corchorus olitorius } & \text { An }\end{array}$

$\begin{array}{lll}\text { Yield }(\%) & 14.5 \pm 0.4 & 13.34 \pm 0.05\end{array}$

Table.3 Some phytochemical constituents of aqueous extract from the leaves of Annonamuricata and Corchorus olitorius

\begin{tabular}{|c|c|c|}
\hline Phytoconstituents & Annona muricata & Corchorus olitorius \\
\hline Alkaloids & - & - \\
\hline Flavonoids & + & + \\
\hline Polyphenols & + & + \\
\hline Saponins & + & + \\
\hline Sterols et terpenes & + & - \\
\hline Catechical tannins & + & + \\
\hline Gallic tannins & - & - \\
\hline
\end{tabular}

(+) Present; (-) Absent

Table.4 Quantitative data of various phytochemicals in the leaves extract of Annona muricataand Corchorus olitorius

\begin{tabular}{lcc}
\cline { 2 - 3 } & $\begin{array}{c}\text { Total flavonoids(mg Eq } \\
\text { quercetin/Kg) }\end{array}$ & $\begin{array}{c}\text { Total polyphenols(mg Eq } \\
\text { gallic acid/g) }\end{array}$ \\
\hline Annona muricata & $329.10 \pm 2.51^{\mathrm{a}}$ & $82.09 \pm 0.13^{\mathrm{a}}$ \\
Corchorus olitorius & $178.45 \pm 1.09^{\mathrm{b}}$ & $67.98 \pm 5.22^{\mathrm{b}}$ \\
\hline
\end{tabular}

Table.5 Antiradical activity of the total aqueous extracts of the leaves of Annona muricata and Corchorus olitorius measured by assay of ABTS

\section{Annona muricata Corchorus olitorius Trolox}

Inhibition concentration $\mathbf{5 0}(\boldsymbol{\mu M}) \quad 1,79 \pm 0,15^{\mathrm{b}} \quad 2,64 \pm 0,05^{\mathrm{a}} \quad 0,95 \pm 0,12^{\mathrm{c}}$

Values are means of triplicate determination $(\mathrm{n}=3) ; \pm$ standard deviation (SD); Means followed by the same letter were not significantly different at $5 \%$ (test of Newman-Keuls). 
Table.6 Antiradical activity of the total aqueous extracts of the leaves of Annona muricata and Corchorus olitorius measured by assay of DPPH

\begin{tabular}{c|ccc}
\hline Concentration (mg/mL) & Annona muricata & Corchorus olitorius & Quercetin \\
\hline 0 & 0 & 0 & 0 \\
50 & $15,34^{\mathrm{d}}$ & $12,65^{\mathrm{d}}$ & $86^{\mathrm{a}}$ \\
100 & $20,98^{\mathrm{d}}$ & $17,89^{\mathrm{d}}$ & $88^{\mathrm{a}}$ \\
200 & $22,04^{\mathrm{c}}$ & $19,04^{\mathrm{d}}$ & $90^{\mathrm{a}}$ \\
250 & $29,37^{\mathrm{c}}$ & $23,98^{\mathrm{c}}$ & $92^{\mathrm{a}}$ \\
500 & $43,44^{\mathrm{c}}$ & $37,31^{\mathrm{c}}$ & $93^{\mathrm{a}}$ \\
750 & $61,77^{\mathrm{b}}$ & $52,09^{\mathrm{b}}$ & $94^{\mathrm{a}}$ \\
1000 & $78,21^{\mathrm{ab}}$ & $66,92^{\mathrm{b}}$ & $95^{\mathrm{a}}$
\end{tabular}

Values are means of triplicate determination $(\mathrm{n}=3) ; \pm$ standard deviation (SD); Means followed by the same letter were not significantly different at $5 \%$ (test of Newman-Keuls).

Figure.1 Method of preparation of total aqueous extracts of Annona muricata and Corchorusolitorius

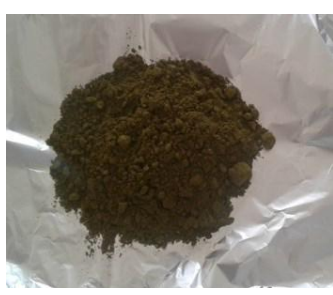

Powder of (Annona muricata or Corchorus olitorius)
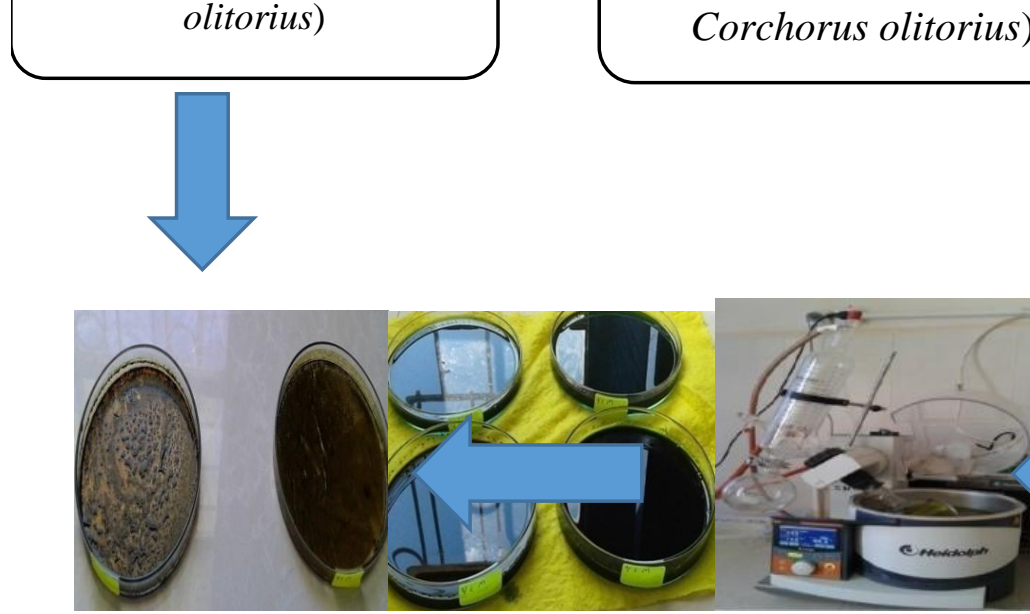

Extracted after drying in the oven

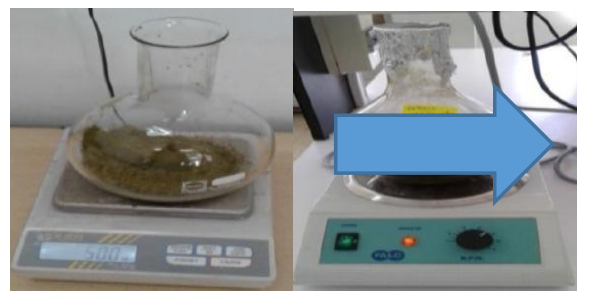

Weight $100 \mathrm{~g}$ of powder of

(Annona muricataor

Corchorus olitorius)

With $1 \mathrm{~L}$ of water

+ agitation

Evaporation 
In conclusion, the cost of treating diabetes is high and beyond the reach of most patients. We undertook this work to make a contribution to the study of the treatment of diabetes. An observation on anti-diabetic medications shows that the plant world has a potential richness in hypoglycemic or anti-hyperglycemic species which deserves to be exploited. A good knowledge of chemical compounds can contribute to the improvement and enhancement of these plants. The results of our study on Annona muricata and Corchorus olitorius revealed the presence of several phytocompounds (flavonoids, polyphenols, saponosides, sterols, catechic tannins and triterpenes). The dosage of some, in particular flavonoids and polyphenols, showed the richness of these plants in these compounds. Finally, the data obtained on antioxidant activity are promoters. However, we believe that studies focused on planned protocols must follow in the footsteps of floristic operations to appreciate the therapeutic value and the limits of use of the recipes. But we believe that an African conception of medicine should be adopted, since people are dying for economic reasons or for out of stock of imported products. The studies carried out on Annona muricata and Corchorus olitorius have given satisfactory results. We believe that further studies are needed to improve this product. We hope this work will contribute to the advancement of traditional medicine and the development of an improved traditional medicine.

\section{References}

Albu S, Joyce E, Paniwnyk L, Lorimer J, Mason T (2004). Potential for the use of ultrasound in the extraction of antioxidants from Rosmarinus officinalis for the food and pharmaceutical industry. Ultrasonics Sonochemistry 11:261-265.

Bahorun T, Gressier B, Trotin F, Brunet C, Dine T, Luyckx M, Vasseur J, Cazin M, Cazin C, Pinkas M (1996). Oxygen species scavenging activity of phenolic extracts from hawthorn fresh plant organs and pharmaceutical preparations. Arznei Forschung 46:1086-1089.

Borokini TI, Omotayo FO (2012). Phytochemical and ethnobotanical study of some selected medicinal plants from Nigeria. Journal of Medicinal Plants Research 6(7):106-118.

Charbonnel B, Cariou B. (1997). Diabète non insulinodépendant et indications thérapeutiques. Médecine thérapeutique 3:103-111.

Choong C, Van-Den T, Roger F, Roger ML (2007). Antioxidant activities, phenolic and beta-carotene contents of sweet potato genotypes with varying flesh colours. Food Chemistry, 103(3), 829-838.

Falleh H, Ksouri R, Chaieb K, Karray-Bouraoui N, Trabelsi N, Boulaaba M, Abdelly C (2007). Phenolic composition of Cynara cardunculus L: organs and their biological activities. Comptes Rendus de Biologie 331:372-379.

Falodun A, Osakue J, Uzoekwe AS, Sheng-Xiang Q (2011). Phytochemical and anticancer studies on ten medicinal plants used in Nigeria. Bayero Journal of Pure and Applied Sciences 4(1):36-39.

Govindan P, Muthukrishnan S (2013). Evaluation of total phenolic content and free radical scavenging activity of Boerhavia erecta. Journal of Acute Medicine 3(3):103-109.

Hollman PCH (2001). Evidence for health benefits of plant phenols: local or systemic effects? Journal of the Science of Food and Agriculture 81(9):842-852.

Huang DJ, Lin CD, Chen HJ, Lin YH (2004). Antioxidant and antiproliferative activities of sweet potato (Ipomoea batatas [L.] Lam 'Tainong 57') constituents. Botanical Bulletin of Academic Sciences 45:179-186.

Kebieche M (2009). Activité biochimique des extraits flavonoïdiques de la plante Ranunculus repens L. : effet sur le diabète expérimental et l'hépatotoxicité induite par l'Epirubicine. Thèse de Doctorat en Biochimie, Université Mentouri Constantine. Faculté des Sciences de la Nature et de la Vie, 143 p.

Kiebre M, Kande PB, Kiebre Z, Sawadogo M, Sawadogo N, Sawadogo B, Traoré RE (2016). Evaluation agromorphologique d'accessions de corète potagère (Corchorus olitorius L) du Burkina Faso [Agromorphological evaluation of accessions of jute potager (Corchorus solitorius L) of Burkina Faso]. International Journal of Innovation and Applied Studies 14(1): 198-200.

Kim SH, Hyun SH, Choung SY (2006). Anti-diabetic effect of cinnamon extract on blood glucose in $\mathrm{db} / \mathrm{db}$ mice. Journal of Ethnopharmacology 104(12):119-123.

Li B, Du Q (2012). Identification of antioxidant compounds of Mucuna sempervirens by high-speed counter-current chromatographic separation-DPPH radical scavenging detection and their oestrogenic activity. Food Chemistry 131:1181-1186.

Maganha GE, Halmenschlager RDC, Rosa MR, Henriques JAP, Paula-Ramos LLA, Saffi J (2010). Pharmacological evidences for the extracts and secondary metabolites from plants of the genus Hibiscus. Food Chemistry 118:1-10. 
Marc F, Davin A, Delgène-Brenbrahim L, Ferrand C, Baccaunaud M, Fritsch P (2004). Méthodes d'évaluation du potentiel d'antioxydant dans les aliments. Médecine/sciences 20: 458-463.

Marinova D, Ribarova F, Atanassova M (2005). Total phenolics in Bulgarian Fruits and vegetables. Journal of the University of Chemical Technology and Metallurgy. 40(3):255-260.

Meddour A, Yahia M, Benkiki N, Ayachi A (2013). Étude de l'activité antioxydante et antibactérienne des extraits d'un ensemble des parties de la fleur du Capparis spinosa L. Journal Lebanese Science14:49-60.

Mohamed ET, El-Sayed Mahdy ME, Singer GAM, ElKiki SM, Elias MS (2017). Role of Annona muricata (L.) in Oxidative Stress and Metabolic Variations in Diabetic and Gamma irradiated Rats. Egyptian Journal of Radiation Sciences and Applications 30(1):73-83.

Morand C, Milenkovic D (2014). Polyphénols et santé vasculaire: mise en évidence du rôle direct des polyphénols dans les effets bénéfiques des agrumes dans la protection vasculaire. Innovations Agronomiques 42:47-62.

Mungole A, Chaturvedi A (2011). Hibiscus sabdariffa L. a rich source of secondary metabolites. International Journal of Pharmaceutical Sciences Rewiev and Research 6:83-87.

Naik AV, Sellappan K (2019). Physicochemical and Phytochemical Analysis of Plant Parts of Annona muricata L (Annonaceae). Pharmaceutical Methods 10(2) :70-78.

Nsemi FM (2010). Identification de polyphénols, évaluation de leur activité antioxydante et étude de leurs propriétés biologiques. Université Paul Verlaine-Metz, 296 p.

Obouayeba AP, Akré DST, Koffi AE, N'dri AFM, Ackah BAAJ, Kouakou TH, N'guessan JD (2019). Evaluation of the role of herbal medicine in primary health care in the city of Daloa (Central-West, Côte d'Ivoire). International Journal of Biosciences 15(4):1-14.

Obouayeba A.P., Ackah J.A.A.B., Yayé Y.G., T.P.V.D. Adiko, Kouakou T.H., Djaman A.J., N'guessan JD (2020). Biological analysis, an essential tool for diagnosis and tracking of pathologies: diabetes. World Journal of Pharmaceutical and Life Sciences 6(8):378-389.

Okou OC, Obouayeba A.P., Yayé YG, Akpoué EV, Djaman AJ (2020). Antiplasmodial effect of Hoslundia opposita Vahl (Lamiaceae) leaves extracts. World Journal of Pharmacy and Pharmaceutical Sciences 9(1):1-17.

Olanrewaju M, Morayo AE, Olawumi AS (2016). Phytochemical evaluation of dry, wet and oil of leaf of Annona muricata for medicinal activities, Journal of Pharmacy and Alternative Medicine 13:42-47.

Ongoka PR, Matini L, Moutou JM, Ngabe DY (2006). Evaluation physico-chimiques et du profil chimique des indicateurs colorés naturels locaux. Cas des extraits de : Hibiscus sabdariffa, Amaranthus oleraceus, Grewia coriacea, Spinacia oleracea et Bougainvillea spectabilis. Annales de l'Université Marien NOUGABI, 7:138-146.

Ouldyerou N, Righi S, Meddah B, Tirtouil A, Bouhadi D, Hariri A (2018). Etude phytochimique et activité antioxydante de quelques plantes antidiabétiques au niveau de la wilaya de mascara. Journal of Advanced Research in Science and Technology 5(1):670-679.

Palsamy P, Subramanian S (2008). Resveratrol, a natural phytoalexin, normalizes hyperglycemia in STZnicotinamide induced experimental diabetic rats. Biomedicine and Pharmaceutical and Therapeutic 62:598-605.

Parejo I, Codina C, Petrakis C, Kefalas P (2000). Evaluation of scavenging activity assessed by Co(II)/EDTA-induced luminal chemilunescence and DPPH (2,2-diphényl-1-pycryl-hydrazyl) free radical assay. Journal of Pharmacology and Toxicology Methodes 44:507-512.

Pietta P (2000). Flavonoids as Antioxidants. Journal of Natural Products 63(7):1035-1042.

Popovici C, Saykova I, Tylkowski B (2009). Evaluation de l'activité antioxydant des composés phénoliques par la réactivité avec le radical libre DPPH. Revue de génie industriel 4:25-39.

Qorina F, Arsianti A, Fithrotunnisa Q, Tejaputri NA (2019). Phytochemistry and antioxidant activity of soursop (Annona muricata) leaves. International Journal of Applied Pharmaceutics 11(6):29-32.

Quy-Diem D, Artik E, Phuong L, Lien H (2014). Effect of extraction solvent on total phenol content, total flavonoid content and antioxidant activity of Limnophila aromatic. Journal of Food and Drug analysis 22(3):296-302.

Raccah D (2004). Epidémiologie et physiopathologie des complications dégénératives du diabète sucré. EMCEndocrinologie. Elsevier SAS 1:29-42.

Roudsari M, Chang P, Pegg R, Robert T, (2009). Antioxidant capacity of bioactives extracted from canola meal by subcritical water, ethanolic and hot water extraction. Food Chemistry, 114: 717-726. 
Sadat A, Hore M, Chakraborty K, Roy S, (2017). Phytochemical analysis and antioxidant activity of methanolic extract of leaves of Corchorus olitorius. International Journal of Current Pharmaceutical Research 9 (5):59-63.

Shimizu M, Kobayashi Y, Suzuki M, Satsu H, Miyamoto Y (2000). Regulation of intestinal glucose transport by tea catechins. Biofactors, 13, 61-65.

Thaouab H, Asma B, Djamila M (2019). Evaluation de l'activité biologique de l'extrait de Corchorus olitorius L. Université Mohamed Khider de Biskra. Mémoire de master, Alger, $48 \mathrm{p}$.

Turkmen N, Velioglu YS, Sari F, Polat G (2007). Effect of extraction conditions on measured total polyphenol contents and antioxidant and antibacterial activities of black tea. Molecules 12(3):484-496.

Sarkhail P, Rahmanipour S, Fadyevatan S (2007). Antidiabetic effect of Phloemic anisodonta: Effects on hepatic cells lipid peroxidation and antioxidant enzymes in experimental diabetes. Pharmaceutical Research56:261-266.

Sarr SO, Fall AD, Gueye R, Diop A, Diatta K, Diop N, Diaye B, Diop YM (2015). Etude de l'activité antioxydante des extraits des feuilles de Vitex doniana (Verbenaceae). International Journal of Biological and Chemical Sciences 9(3):1263-1269.

Usunobun U, Okolie NP, Anyanwu OG, Adegbegi AJ (2015). Phytochemical screening and proximate composition of Annona muricata leaves. European Journal of Botany Plant Science and Pathology 2(1):18-28.

Usunomena U, Paulinus ON, (2015). Phytochemical analysis and mineral composition of Annona muricata leaves. International Journal of Research and Current Development 1(1):38-42.

Vijayameena C, Subhashini G, Loganayagi M, Ramesh B (2013). Phytochemical screening and assessment of antibacterial activity for the bioactive compounds in Annona muricata. Int. Journal of Current Microbiologie and Applied Sciences 2(1):1-8.

\section{How to cite this article:}

Abba P. Obouayeba, Obou C. Okou, Bognan J.A.A. Ackah, Bi-Tra L. Tra, Tanoh H. Kouakou, Allico J.Djaman and Jean D.N'guessan. 2021. Phytochemical Study and Antioxidant Activity of Annona muricata (Annonaceae) and Corchorus olitorius (Tiliaceae) Two Medicinal Plants from the Ivorian Pharmacopoeia Used in the Treatment of Diabetes. Int.J.Curr.Res.Aca.Rev. 9(01), 31-42. doi: https://doi.org/10.20546/ijcrar.2021.901.002
Vya B, Boye A, Quansah N (2013). Antioxidant and wound healing studies on the extracts of Corchorus olitorius leaf. World Essays Journal 7: 67-73.

Wang W, Wu NN, Zu YG, Fu YJ (2008). Antioxidant activity of $\mathrm{R}$. officinalis $\mathrm{L}$ oil compared to its main compounds. Journal of Food chemistry 108(3):1019-1022.

Wood JE, Senthilmohan ST, Peskin AV (2002). Antioxidant activity of procyanidin-containing plant extracts at different pHs. Food Chemistry 77: 155161.

Yang J, Gadi R, Paulino R, Thomson T (2010). Total phenolic, ascorbic acid, and antioxidant capacity of noni (Morinda citrifolia L.) juice and powder as affected by illumination during storage. Journal of Food chemistry 122(3):627-632.

Yayé YG, Obouayeba AP, Ackah JAAB, Djaman AJ (2020). Optimization of antifungal activity and chemical study of Terminalia mantaly extracts. Journal of Pharmacognosy and Phytochemistry 9(5):700-705.

Zidorn C (2010). Altitudinal variation of secondary metabolites in flowering heads of the Asteraceae: trends and cause. Phytochemistry Review 9(2):197203.

Zine S. (2018). Le corossol (Annona muricata 1.) et ses propriétés thérapeutiques : état des lieux. Thèse de doctorat, faculté de pharmacie, Université de Grenoble, Alpes Faculté de pharmacie de Grenoble, $62 \mathrm{p}$.

Zirihi GN, N'guessan K, Etien DT, Grellier P (2010). Ethnopharmacological study of plants used to treat malaria, in traditional medicine, by Bete Populations of Issia (Côte d'Ivoire). Journal of Pharmaceutical Sciences and Research 2(4):216227.

Zurina H, Yam MF, Ahmad M, Yusof APM (2010). Antidiabetic properties and mechanism of action of Gynura procumbens water extract in streptozotocininduced diabetic rats. Molecules, 15:9008-9023. 